\title{
The impact of oxidiser humidity on methane combustion in a gas burner
}

\author{
Andrii N. Avramenko \\ A. Podgorny Institute for Mechanical Engineering Problems of the National Academy of Sciences \\ of Ukraine, Str. Pozharskogo, 2/10, 61046 Kharkiv, Ukraine \\ an0100@ukr.net
}

Keywords: methane combustion, air humidity, environmental indicators, monoxide nitrogen, Zeldovich thermal mechanism.

The improvement of thermodynamic and environmental indicators of energy facilities is a vital and topical problem. Numerical simulation methods are used to investigate the processes of combustion and formation of hazardous substances by computation, and to work out recommendations on increasing the effectiveness of fuel combustion. The paper examines the impact of atmospheric air humidity on the process of combustion of a stoichiometric methane-air mixture in a burner. The combustion process is simulated in the $3 \mathrm{D}$ unsteady statement in Cartesian coordinates. In the investigation, the combustion of the methane-air mixture is considered in one stage. Air humidity is considered in the 0 to $100 \%$ range. The monoxide nitrogen formation process is described using the extended Zeldovich-Fenimore mechanism. A comparative study has found that increasing air humidity up to $100 \%$ reduces the mass emission of monoxide nitrogen by a factor of 1.27 , as compared to dry air. The study results can be used for designing equipment that uses methane as fuel.

\section{Introduction}

Methane as fuel is used extensively in the power, chemical, oil-and-gas, and food and civil engineering industries. Many scientists were engaged in experimental and numerical investigation of the process of combustion [1-4] in particular of methane-air mixtures $[3,4]$. The process of combustion of methane in the DLE Siemens SGT-800 burner was considered in detail [5]. Turbulent flows were described using numerical methods with the solving of Reynolds averaged Navier-Stokes equations [5]. A close fit of computational and experimental results was shown to be achieved [5]. The process of combustion of a methane-air mixture without premixing was studied [6].

The possibility of using a steady laminar flamelet model (SFM) for simulating the process of combustion of a methane-air mixture was studied [6]. The study conducted has shown that increasing the number of turbulising inserts and the flow turbulisation level reduces the emission of thermal NO [6]. The authors investigated the process of combustion of a methane-air mixture 
using a standard $k-\varepsilon$ turbulence model with account of radiation heat exchange [7]. However, as follows from the constraints of the $k-\varepsilon$ turbulence model, and with account of recommendations $[8,9]$, the SST turbulence model offers better convergence to experimental results when the process of high-rate combustion of a methane-air mixture is described. The authors studied the role of water and water vapour in the processes of methane combustion with the purpose of reducing nitrogen and carbon oxides emission, though the impact of flow turbulisation at high velocities was not investigated, and near-wall effects were not accounted for [10]. The study did not investigate the impact of flow turbulisation at high rates and account for near-wall effects.

The problem related to investigation of the impact of atmospheric air humidity on the process of high-rate combustion of the methaneair mixture and flow turbulisation is still poorly studied.

\section{Materials and methods}

The study simulates the process of combustion of the stoichiometric methane-air mixture in the 3D unsteady statement.

The structure of research is shown in Fig. 1.

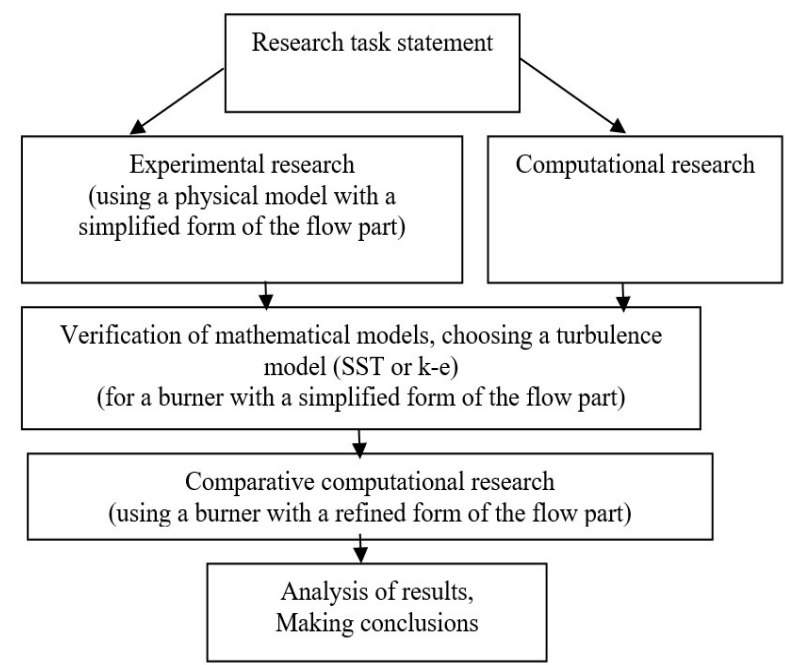

Figure 1. The structure of research

\section{Experimental part}

Experimental research on a physical model of a burner with a simplified form of the flow part was conducted for an operating condition with air humidity $50 \%$.

The general view of the experimental installation is shown in Fig. 2.

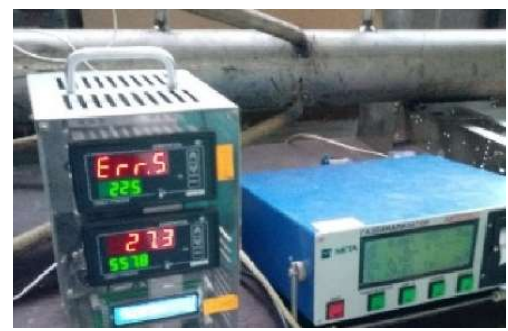

Figure 2. The general view of the experimental installation The scheme of air and fuel feeding is shown in Fig. 3.

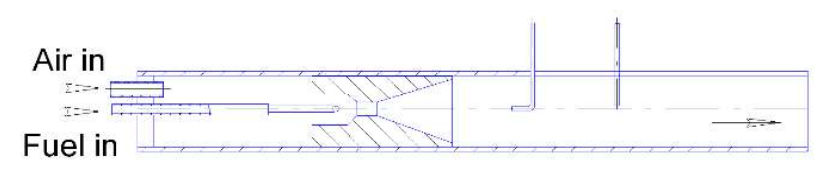

Figure 3. The scheme of air and fuel feeding

During the experiment, the following was controlled: air and fuel flow rate and temperature, exhaust gas composition (with a 5component gas analyser) and the exhaust gases 
temperature (using a chromel-copel thermocouple in a stagnated flow).

Fig. 4 shows the measurement schematic diagram.

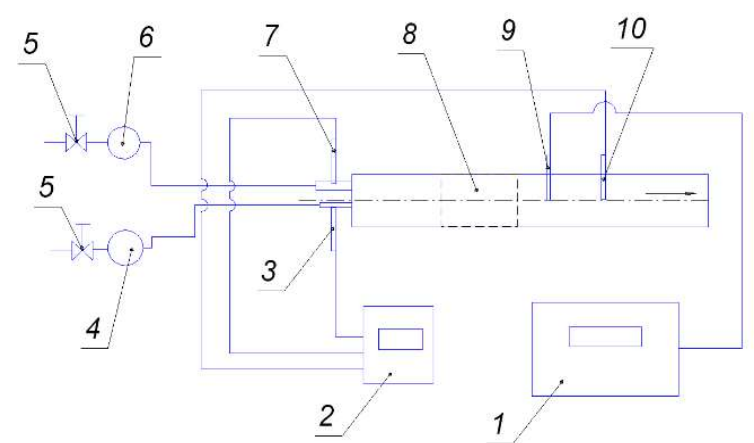

1 - gas analyzer; 2 - device for recording temperature; 3 gas temperature sensor; 4 - gas flow meter; 5 - valve; 6 air flow meter; 7 - air temperature sensor; 8 - burner; 9 sampler; 10 - exhaust gas temperature sensor.

Figure 4. The measurement schematic diagram

The process of combustion of hydrocarbon fuel can be computed using the following relationship:

$$
\begin{aligned}
& \mathrm{CH}_{n}+\frac{\alpha_{s}}{\phi} \cdot\left(\mathrm{O}_{2}+3.78 \mathrm{~N}_{2}\right) \rightarrow \mathrm{CO}_{2}+ \\
& +\frac{n}{2} \cdot \mathrm{H}_{2} \mathrm{O}+\alpha_{s}\left(\frac{1}{\phi}-1\right) \cdot \mathrm{O}_{2}+\frac{3.78 \alpha_{s}}{\phi} \cdot N_{2},
\end{aligned}
$$

SST and $k-\varepsilon$ turbulence models are used to describe turbulent flows in a burner with a simplified form of the flow part, with account of recommendations in papers [7-9].

The SST turbulence model equations have the form:

$\frac{\partial(\rho k)}{\partial t}+\frac{\partial\left(\rho u_{j} k\right)}{\partial x_{j}}=P-\beta^{*} \rho \omega k+\frac{\partial}{\partial x_{j}}\left[\left(\mu+\sigma_{k} \mu_{t}\right) \frac{\partial k}{\partial x_{j}}\right]$

$\frac{\partial(\rho \omega)}{\partial t}+\frac{\partial\left(\rho u_{j} \omega\right)}{\partial x_{j}}=\frac{\gamma}{\vartheta_{\tau}} P-\beta \rho \omega^{2}+\frac{\partial}{\partial x_{j}}$

$$
\left[\left(\mu+\sigma_{\omega} \mu_{t}\right) \frac{\partial \omega}{\partial x_{j}}\right]+2\left(1-F_{1}\right) \frac{\rho \sigma_{\omega 2}}{\omega} \frac{\partial k}{\partial x_{j}} \frac{\partial \omega}{\partial x_{j}},
$$

where $\mu_{t}$ is turbulent eddy viscosity, $F_{l}$ are additional functions, $v_{t}$ is turbulent kinematic viscosity, $\beta, \beta^{*}, \gamma, \sigma_{k}, \sigma_{\omega}$ are constants.

The standard $k-\varepsilon$ model equations have the form:

$$
\begin{aligned}
& \frac{\partial}{\partial t}(\rho \cdot k)+\frac{\partial}{\partial x_{i}}\left(\rho \cdot k \cdot \bar{u}_{i}\right)=\frac{\partial}{\partial x_{j}}\left[\left(\mu+\frac{\mu_{t}}{\sigma_{k}}\right) \frac{\partial k}{\partial x_{j}}\right]+ \\
& +G_{k}+G_{b}-\rho \cdot \varepsilon-Y_{M}+S_{k}, \\
& \frac{\partial}{\partial t}(\rho \cdot \varepsilon)+\frac{\partial}{\partial x_{i}}\left(\rho \cdot \varepsilon \cdot \bar{u}_{i}\right)=\frac{\partial}{\partial x_{j}}\left[\left(\mu+\frac{\mu_{t}}{\sigma_{\varepsilon}}\right) \frac{\partial \varepsilon}{\partial x_{j}}\right]+ \\
& +G_{1 \varepsilon} \frac{\varepsilon}{k}\left(G_{k}+C_{3 \varepsilon} \cdot G_{b}\right)-C_{2 \varepsilon} \cdot \rho \frac{\varepsilon^{2}}{k}+S_{\varepsilon} .
\end{aligned}
$$

$\mathrm{k}$ is specific kinetic turbulent energy; $\varepsilon$ is rate of viscous dissipation of turbulent energy; $\rho$ is gas density; $\mu_{t}$ is turbulent dynamic viscosity; $\bar{u}_{i}$ is averaged velocity; $\sigma_{k}$ is a dimensionless empirical constant; $G_{k}$ is turbulent kinetic energy formed by mean velocity gradients; $G_{b}$ is displacement force kinetic energy; $C_{3 \varepsilon}, C_{2 \varepsilon}$ are constants; $Y_{M}$ is the contribution of the variable expansion during compression turbulence to the total dissipation rate; $S_{k}$ is invariant of the strain tensor.

The description of the intricate heat transfer between the gas, flame and walls in the paper accounts for radiant heat transfer by using the P1 model $[11,12]$. The equation of the P1 radiant heat transfer model has the form:

$$
q_{\Gamma}=-\frac{1}{3\left(\alpha+\sigma_{s}\right)-C \sigma_{s}} \cdot \nabla G
$$


where $\alpha$ is absorption coefficient, $\sigma_{s}$ is scattering coefficient, $G$ is incident radiation, $C$ is linearanisotropic phase function coefficient.

Next, the mathematical models were verified and a turbulence model (SST or $k-\varepsilon$ ) was chosen for a burner with a simplified form of the flow part.

The process of combustion of a methaneair mixture is very intricate and a detailed description of the mechanism comprises 52 chemical reaction equations [13].

In the process of combustion of a hydrocarbon fuel, nitrogen oxides are presented by the series: $\mathrm{NO}, \mathrm{NO}_{2}, \mathrm{~N}_{2} \mathrm{O}, \mathrm{N}_{2} \mathrm{O}_{3}, \mathrm{~N}_{2} \mathrm{O}_{5}, \mathrm{~N}_{2} \mathrm{O}_{4}$. As it is known, NO contributes most to the total emission of nitrogen oxides [14].

It is also worth mentioning a study that substantiated the expediency of a simplified investigation of the process of formation of nitrogen oxides during the combustion of a methane-air mixture [15]. An attempt to account for all the chains in the forward and counter reactions makes it impossible to simulate turbulent flames, with a negative impact on simulation accuracy [15]. The study has shown [15] that, since the NO formation reaction requires big activation energies, the most significant impact is that of turbulent temperature pulsations and the concentration of reacting substances.

Using numerical methods, a limited number of chemical reactions is usually considered.
In this study, the combustion of the methane-air mixture was considered in several stages:

$$
\begin{gathered}
\mathrm{CH}_{4}+2 \mathrm{O}_{2}=\mathrm{CO}_{2}+2 \mathrm{H}_{2} \mathrm{O} \\
\mathrm{CH}_{4}+2 \mathrm{O}_{2} \sim \mathrm{CO}_{2}+2 \mathrm{H}_{2} \mathrm{O}+\mathrm{CO}+\mathrm{H}+\mathrm{C} \\
\mathrm{CH}_{4}+3 \mathrm{O}_{2}+\mathrm{N}_{2}=\mathrm{CO}_{2}+2 \mathrm{NO}+2 \mathrm{H}_{2} \mathrm{O}
\end{gathered}
$$

In the paper, the formation of monoxide nitrogen (NO) is described using the thermal mechanism suggested by Ya.B. Zeldovich and Fenimore's mechanism of the so-called "prompt" NO [16, 17].

Formation of thermal NO comprises a three-stage mechanism:

$$
\begin{gathered}
\mathrm{O}+\mathrm{N}_{2} \leftrightarrow \mathrm{NO}+\mathrm{N} \\
\mathrm{N}+\mathrm{O}_{2} \leftrightarrow \mathrm{NO}+\mathrm{O} \\
\mathrm{OH}+\mathrm{N} \leftrightarrow \mathrm{NO}+\mathrm{H} .
\end{gathered}
$$

Formation of prompt NO has the form:

$$
\begin{gathered}
\mathrm{CH}+\mathrm{N}_{2}=\mathrm{HCN}+\mathrm{N} \\
2 \mathrm{C}+\mathrm{N}_{2}=2 \mathrm{CN} \\
\mathrm{CH}_{2}+\mathrm{N}_{2}=\mathrm{NC}+\mathrm{NH} .
\end{gathered}
$$

\section{Thermal NO formation}

The principal reactions governing the formation of thermal $\mathrm{NO}_{\mathrm{x}}$ from molecular nitrogen are as follows:

$$
\begin{gathered}
O+N_{2} \stackrel{k_{+1}}{\Leftrightarrow} N+N O \\
N+O_{2} \stackrel{k_{+2}}{\Leftrightarrow} O+N O \\
N+O H \stackrel{k_{+3}}{\Leftrightarrow} H+N O \\
k_{1}=1.8 \cdot 10^{8} e^{-383870 / T} \\
k_{-1}=3.8 \cdot 10^{7} e^{-425 / T} \\
k_{2}=1.8 \cdot 10^{4} \mathrm{Te}^{-4680 / T} \\
k_{-2}=3.8 \cdot 10^{3} T e^{-20820 / T}
\end{gathered}
$$




$$
\begin{aligned}
k_{3} & =7.1 \cdot 10^{7} e^{-425 / T} \\
k_{-3} & =1.7 \cdot 10^{8} e^{-24560 / T}
\end{aligned}
$$

where $k_{1}, k_{2}, k_{3}$ - is the rate constants for the forward reactions, respectively, and $k_{-1}, k_{-2}, k_{-3}$ - is the corresponding reverse rates. All of these rates have units of $\mathrm{m}^{3} / \mathrm{g} \mathrm{mol}-\mathrm{s}$.

The net rate of formation of $\mathrm{NO}$ via reactions is given by:

$$
\begin{aligned}
& \frac{d[N O]}{d t}=k_{1}[O]\left[N_{2}\right]+k_{2}[N]\left[O_{2}\right]+k_{3}[N][O H]- \\
& -k_{-1}[N O][N]-k_{-2}[N O][O]-k_{-3}[N O][H]
\end{aligned}
$$

To calculate the formation rates of $\mathrm{NO}$ and $\mathrm{N}$, the concentrations of $\mathrm{O}, \mathrm{H}$, and $\mathrm{OH}$ are required.

\section{Prompt NOx mechanism}

Prompt $\mathrm{NO}_{\mathrm{x}}$ is most prevalent in rich flames. The route now accepted is as follows:

$$
\begin{aligned}
& \mathrm{CH}+\mathrm{N}_{2} \Leftrightarrow \mathrm{HCN}+\mathrm{N} \\
& \mathrm{N}+\mathrm{O}_{2} \Leftrightarrow \mathrm{NO}+\mathrm{O} \\
& \mathrm{HCN}+\mathrm{OH} \Leftrightarrow \mathrm{CN}+\mathrm{H}_{2} \mathrm{O} \\
& \mathrm{CN}+\mathrm{O}_{2} \Leftrightarrow \mathrm{NO}+\mathrm{CO} \\
& \mathrm{CH}_{2}+\mathrm{N}_{2} \Leftrightarrow \mathrm{HCN}+\mathrm{NH}
\end{aligned}
$$

Primary reaction is:

$$
\frac{d[N O]}{d t}=k_{0}[C H]\left[N_{2}\right]
$$

In the early stages of the flame:

$$
\begin{aligned}
& \frac{d[N O]}{d t}=k_{p r}\left[O_{2}\right]^{a}\left[N_{2}\right][F U E L] e^{-E_{a} / R T} \\
& k_{p r}=1.2 \cdot 10^{7}(R T / p)^{a+1} \\
& E_{a}=60 \mathrm{kcal} / \mathrm{g} \mathrm{mol}
\end{aligned}
$$

where $a$ - is the oxygen reaction order, $R$ - is the universal gas constant, and $p$ - is pressure.
The flow part of gas burners considered in the study is a body of rotation with a tapering section (the nozzle).

The shape of the burner with a simplified form of the flow part is shown in Fig. 5, and the scheme for specifying the boundary conditions and their values is given in Fig. 5 and in the Table 1.

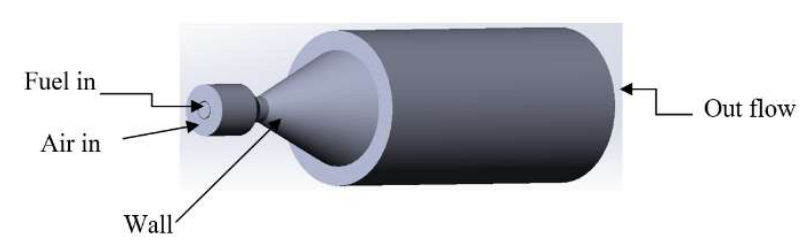

Figure 5. Schematic for specifying boundary conditions

Table 1. Values of boundary conditions

\begin{tabular}{|c|c|c|}
\hline Boundary & Boundary type & Value \\
\hline \multirow{2}{*}{ Air in } & Inlet velocity, $\mathrm{m} / \mathrm{s}$ & 2.5 \\
\cline { 2 - 3 } & Temperature, ${ }^{\circ} \mathrm{C}$ & 27.3 \\
\hline \multirow{2}{*}{$\begin{array}{c}\text { Fuel in } \\
(6 \text { holes })\end{array}$} & Inlet velocity, $\mathrm{m} / \mathrm{s}$ & 2 \\
\hline \multirow{2}{*}{ Outflow } & Temperature, ${ }^{\circ} \mathrm{C}$ & 22.5 \\
\hline \multirow{2}{*}{ Wall } & Excess pressure, $\mathrm{MPa}$ & 0 \\
\cline { 2 - 3 } & Ambient temperature, ${ }^{\circ} \mathrm{C}$ & 27 \\
\cline { 2 - 3 } & Ambient temperature, ${ }^{\circ} \mathrm{C}$ & 27 \\
\cline { 2 - 3 } & $\begin{array}{c}\text { Heat rejection ratio, } \\
\mathrm{W} /\left(\mathrm{m}^{2} \mathrm{~K}\right)\end{array}$ & 300 \\
\cline { 2 - 3 } & Wall roughness, $\mu \mathrm{m}$ & 30 \\
\hline
\end{tabular}

Fig. 6-7 shows the results of the comparative computational research.

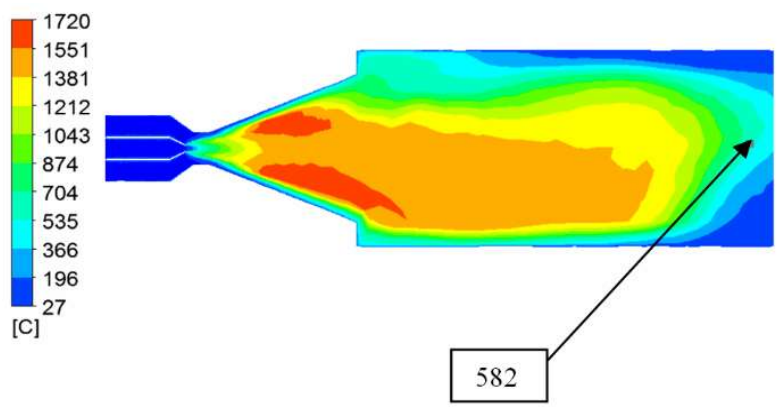

$1-\mathrm{SST}$ 

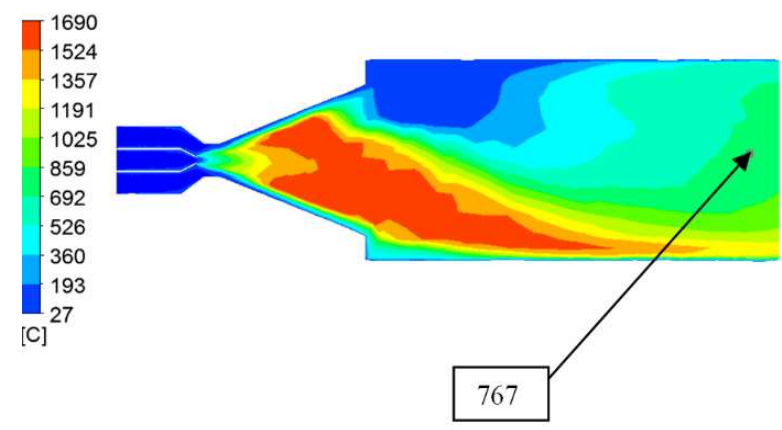

\section{$2-k-\varepsilon$}

Figure 6. Gas and flame temperature, ${ }^{\circ} \mathrm{C}$, pattern during combustion of the methane-air mixture versus air humidity $50 \%$
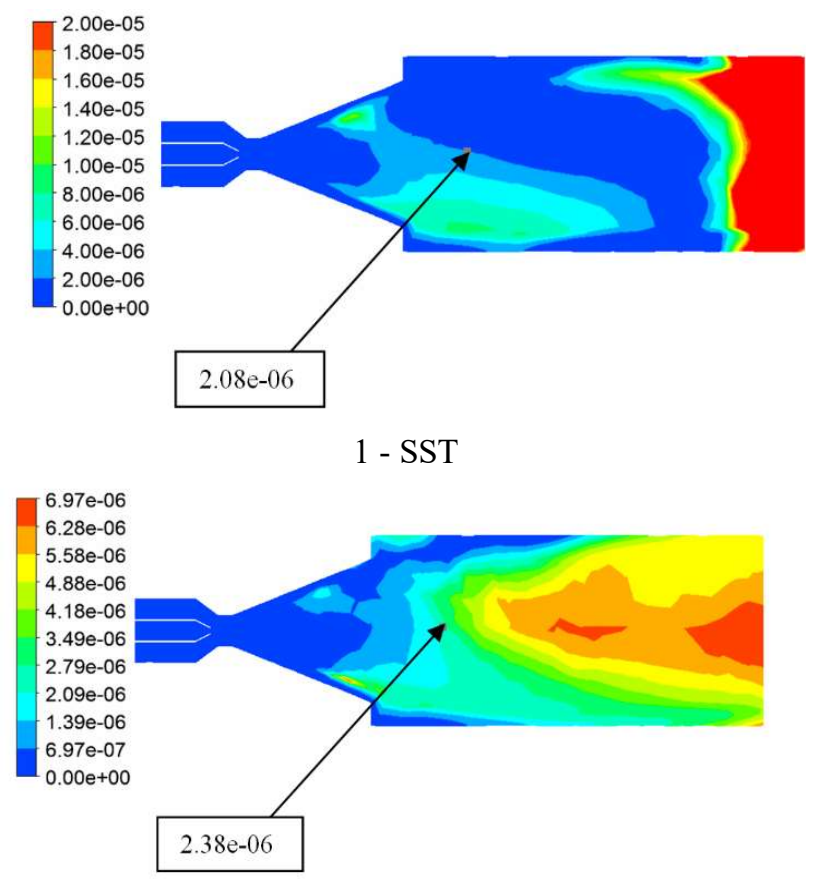

$$
2-k-\varepsilon
$$

Figure 7. NO mass fraction pattern during combustion of the methane-air mixture versus air humidity $50 \%$

The results show (Fig. 6-7) that using the $k-\varepsilon$ turbulence model yields more accurate numerical simulation results.

Based on the research conducted, the $k-\varepsilon$ turbulence model will be used in further computations.
The gas burner flow part is a body of rotation with a contraction (a nozzle). The burner length is $150-\mathrm{mm}$; the nozzle diameter is 14 $\mathrm{mm}$; the cone base diameter (outlet part) is 60 $\mathrm{mm}$. The study uses the finite-volume method for numerical simulation of the process of combustion of the methane-air mixture in the burner.

Three variants of computational domain discretisation were considered in the paper to increase the accuracy of simulation results. The computational grids used for numerical simulation are shown in Figure 8 , and their dimensions are given in Table 2.

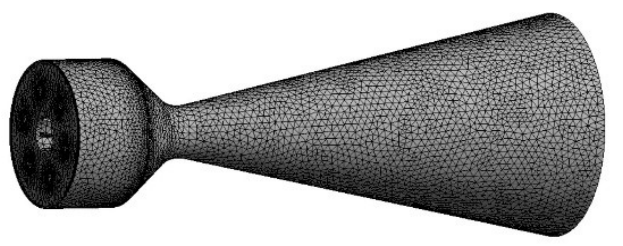

1

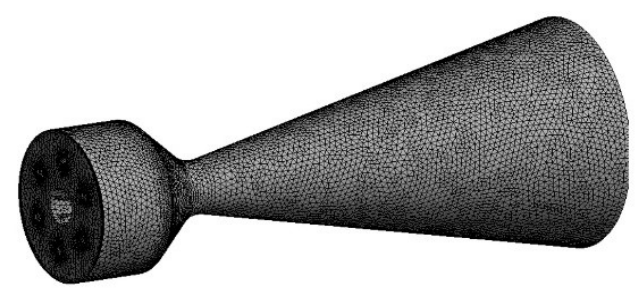

2

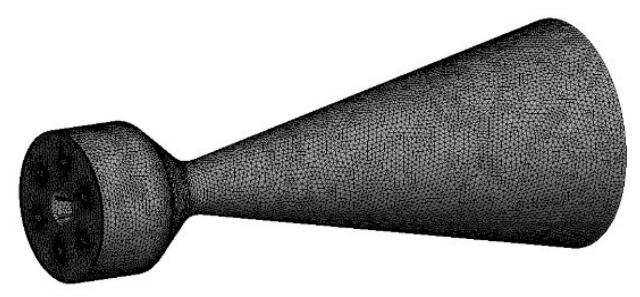

3

Figure 8. Variants of computational grids

Table 2. Number of computational cells with a different level of discretisation of the computational domain of the gas burner

\begin{tabular}{|c|c|c|c|}
\hline Variant & 1 & 2 & 3 \\
\hline $\begin{array}{c}\text { Number of computational } \\
\text { cells, mln. }\end{array}$ & 0.25 & 0.4 & 0.5 \\
\hline
\end{tabular}


The computational grid was adapted [18, 19] to increase the accuracy of simulating the near-wall effects during gas flow and combustion. The paper uses computational grids with five layers in the near-wall layer with a minimal computational cell height of $0.1 \mathrm{~mm}$.

Figure 9 shows the schematic for specifying boundary conditions $(\mathrm{BC})$, and Table 3 gives the $\mathrm{BC}$ values.

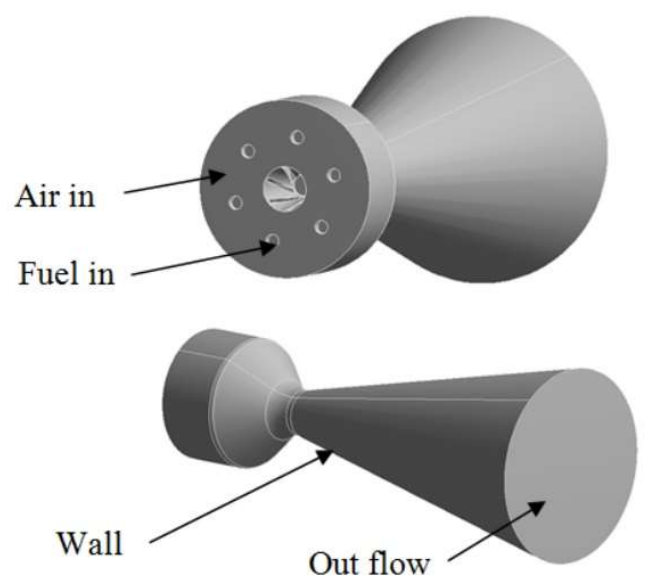

Figure 9. Schematic for specifying boundary conditions

Table 3. Values of boundary conditions

\begin{tabular}{|c|c|c|}
\hline Boundary & Boundary type & Value \\
\hline \multirow{2}{*}{ Air in } & Inlet velocity, $\mathrm{m} / \mathrm{s}$ & 1 \\
\cline { 2 - 3 } & Temperature, ${ }^{\circ} \mathrm{C}$ & 25 \\
\hline $\begin{array}{c}\text { Fuel in } \\
\text { (6 holes) }\end{array}$ & Inlet velocity, $\mathrm{m} / \mathrm{s}$ & 2.82 \\
\cline { 2 - 3 } Out flow & Temperature, ${ }^{\circ} \mathrm{C}$ & 25 \\
\hline \multirow{2}{*}{ Wall } & Excess pressure, $\mathrm{MPa}$ & 0 \\
\cline { 2 - 3 } & Ambient temperature, ${ }^{\circ} \mathrm{C}$ & 25 \\
\cline { 2 - 3 } & Ambient temperature, ${ }^{\circ} \mathrm{C}$ & 25 \\
\cline { 2 - 3 } & $\begin{array}{c}\text { Heat rejection ratio, } \\
\mathrm{W} /\left(\mathrm{m}^{2} \mathrm{~K}\right)\end{array}$ & 300 \\
\cline { 2 - 3 } & Wall roughness, $\mu \mathrm{m}$ & 30 \\
\hline
\end{tabular}

Air humidity values during numerical simulation are given in Table 4.
Table 4. Atmospheric air humidity

\begin{tabular}{|c|c|c|c|c|c|c|}
\hline $\begin{array}{c}\text { Variant } \\
\text { No. }\end{array}$ & 1 & 2 & 3 & 4 & 5 & 6 \\
\hline $\begin{array}{c}\text { Air } \\
\text { humidity, } \\
\%\end{array}$ & 0 & 25 & 50 & 75 & 90 & 100 \\
\hline $\begin{array}{c}\text { Grams of } \\
\mathrm{H}_{2} \mathrm{O} \text { per } \\
\mathrm{kg} \text { of air }\end{array}$ & 0 & 4.99 & 9.98 & 14.97 & 17.97 & 19.96 \\
\hline
\end{tabular}

\section{Results}

The results of comparative numerical simulation of the processes of combustion and formation of combustion products are shown in Figure 10-13.

Figure 10 shows the flow velocity pattern. The maximum velocity is in the nozzle zone, and it reaches $49 \mathrm{~m} / \mathrm{s}$. At a distance from the nozzle, the flow velocity drops from 30 to 12 $\mathrm{m} / \mathrm{s}$.

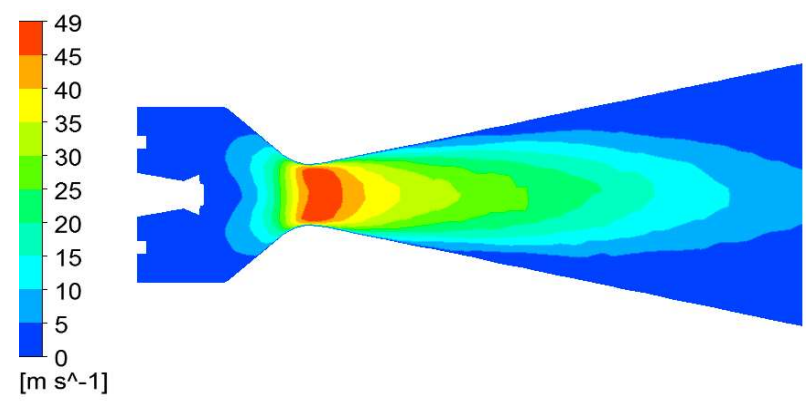

Figure 10. Flow velocity pattern during combustion of the methane-air mixture (humidity $75 \%$ )

Air humidity in the range being studied has virtually no effect on gas flow and flame velocity. Figure 11 shows the gas and flame temperature pattern during combustion of the methane-air mixture. 


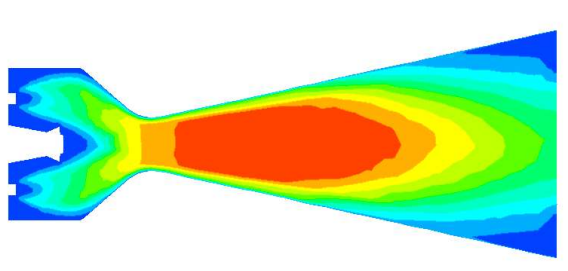

a)

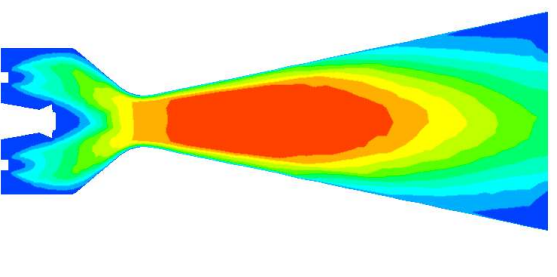

b)

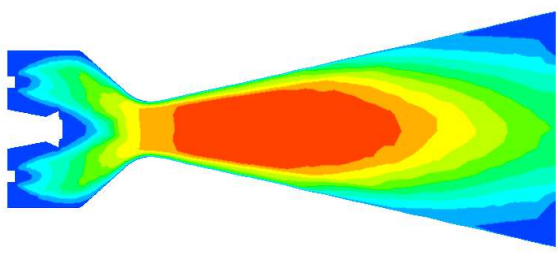

c)

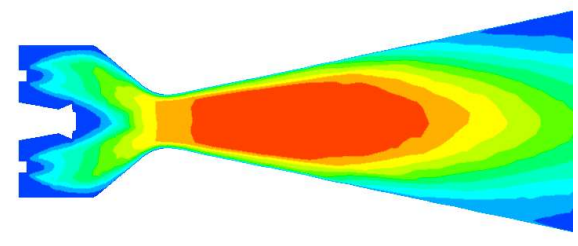

d)

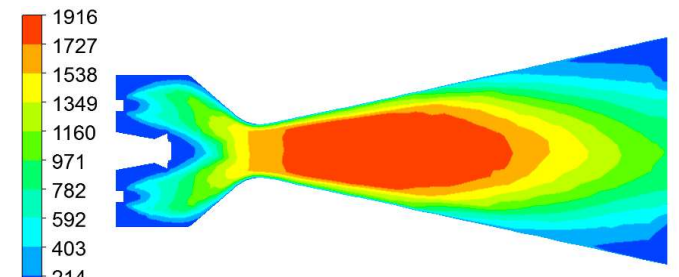

e)

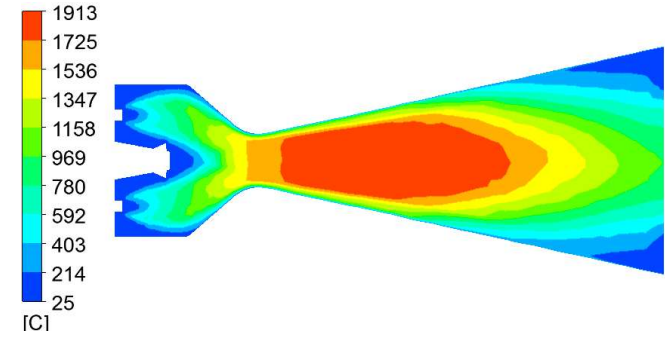

f)

Figure 11. Gas and flame temperature, ${ }^{\circ} \mathrm{C}$, pattern during combustion of the methane-air mixture versus air humidity: $a-0 \%, b-25 \%, c-50 \%, d-75 \%, e-90 \%, f-100 \%$

The results show that, with increasing air humidity, the maximum flame temperature drops. For the computation variant with $0 \%$ humidity (Figure 11, a), the maximum temperature reaches $1,944{ }^{\circ} \mathrm{C}$. For the computation variant with 25\% humidity (Figure 11, b), the maximum temperature reaches 1,936 ${ }^{\circ} \mathrm{C}$. For the computation variant with $50 \%$ humidity (Figure 11, c), the maximum temperature reaches $1,928{ }^{\circ} \mathrm{C}$. For the computation variant with 75\% humidity (Figure 11, d), the maximum temperature reaches 1,921 ${ }^{\circ} \mathrm{C}$. For the computation variant with $90 \%$ humidity (Figure 11, e), the maximum temperature reaches $1,916{ }^{\circ} \mathrm{C}$. For the computation variant with $100 \%$ humidity (Figure 11, f), the maximum temperature reaches $1,913{ }^{\circ} \mathrm{C}$.

Figure 12 shows the monoxide nitrogen mass fraction pattern during combustion of the methane-air mixture. 


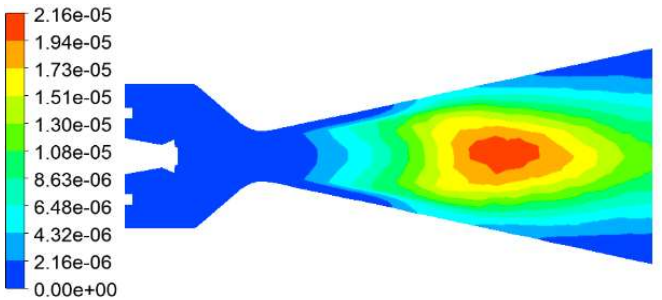

a)

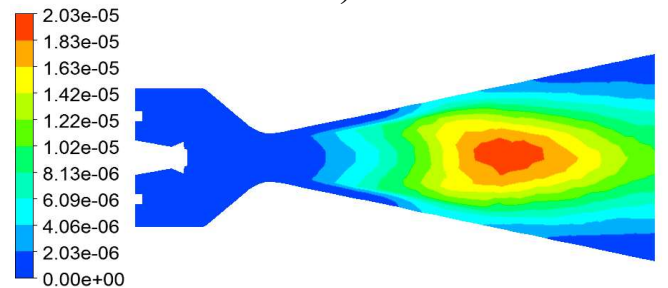

b)

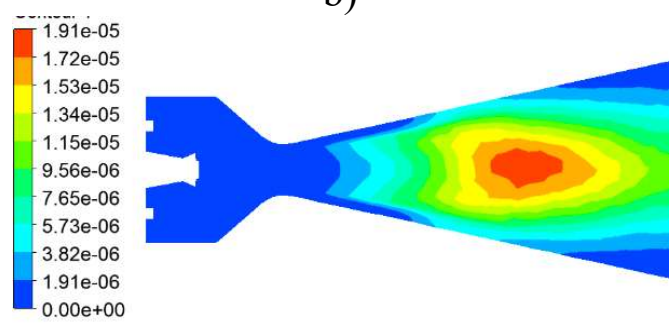

c)

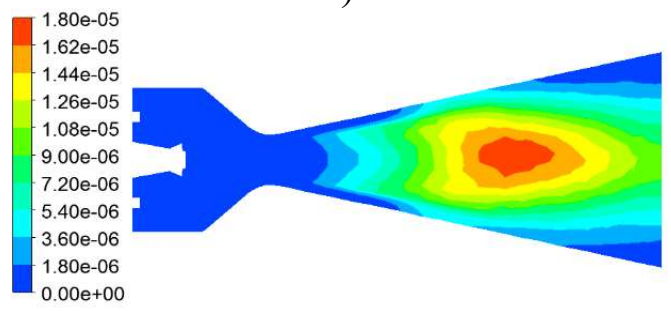

d)

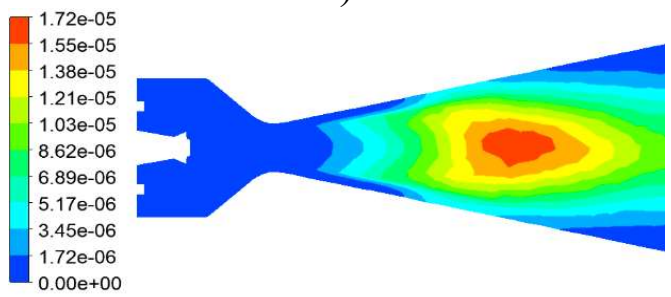

e)

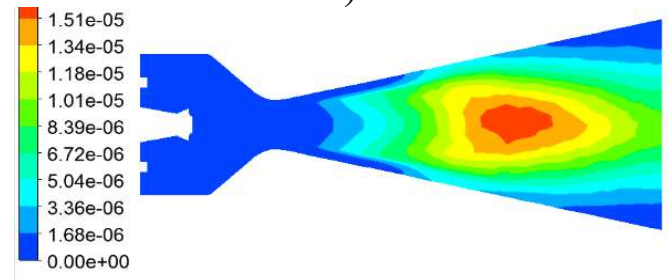

f)

Figure 12. NO mass fraction pattern during combustion of the methane-air mixture versus air humidity:

$a-0 \%, b-25 \%, c-50 \%, d-75 \%, e-90 \%, f-100 \%$
The results show that with increasing air humidity the NO mass fraction drops (Figure 12). In the range studied, with increasing air humidity from 0 to $100 \%$, the NO mass fraction drops from $2.16 \cdot 10^{-5}$ to $1.51 \cdot 10^{-5}$.

Figure 13 shows the carbon dioxide mass fraction pattern during combustion of the methane-air mixture.

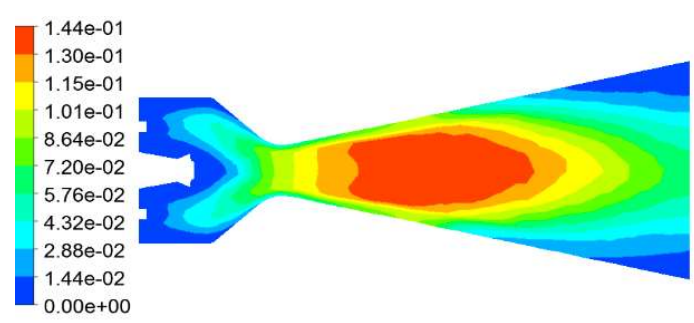

Figure 13. $\mathrm{CO}_{2}$ mass fraction pattern during combustion of the methane-air mixture (humidity $75 \%$ )

\section{Discussion}

The air humidity in the range studied has virtually no effect on the $\mathrm{CO}_{2}$ mass fraction pattern. The correctness of the problem statement and solution were appraised with account of the mass balance at the gas burner inlet and outlet (Table 5).

Table 5. Mass balance at gas burner inlet and outlet

\begin{tabular}{|c|c|}
\hline Inlet flow & Out flow \\
\hline Air and fuel & Combustion products \\
\hline $\mathrm{g} / \mathrm{s}$ & $\mathrm{g} / \mathrm{s}$ \\
\hline 1.4019 & 1.4005 \\
\hline
\end{tabular}

The results (Table 5) show that the problem solution demonstrated good convergence of numerical simulation results, which is indicative of correct problem statement and solution. 
Table 6 shows the impact of the discretisation level on numerical simulation results.

Table 6. Impact of the discretisation level on numerical simulation results (for $75 \%$ air humidity)

\begin{tabular}{|c|c|c|c|}
\hline $\begin{array}{c}\text { Number of } \\
\text { computational } \\
\text { cells, mln. }\end{array}$ & $\begin{array}{c}\text { Maximum } \\
\text { temperature, } \\
{ }^{\circ} \mathrm{C}\end{array}$ & $\begin{array}{c}\text { NO mass } \\
\text { fraction }\end{array}$ & $\begin{array}{c}\mathrm{CO}_{2} \text { mass } \\
\text { fraction }\end{array}$ \\
\hline 0.25 & 1,930 & $1.87 \mathrm{E}-05$ & $1.46 \mathrm{E}-01$ \\
\hline 0.4 & 1,918 & $1.82 \mathrm{E}-05$ & $1.43 \mathrm{E}-01$ \\
\hline 0.5 & 1,921 & $1.8 \mathrm{E}-05$ & $1.44 \mathrm{E}-01$ \\
\hline
\end{tabular}

The results (Table 6) demonstrate that it is impractical to increase the number of computational cells (to over $0.5 \mathrm{mln}$.) because this increases problem dimensionality without a significant increase in the accuracy of numerical simulation results.

The summarised results of comparative numerical research in air humidity impact on mass NO emission are given in Table 7.

Table 7. Air humidity impact on NO mass emission

\begin{tabular}{|c|c|c|c|c|c|c|}
\hline $\begin{array}{c}\text { Air } \\
\text { humidity, } \\
\%\end{array}$ & 0 & 25 & 50 & 75 & 90 & 100 \\
\hline $\begin{array}{c}\text { NO mass } \\
\text { emission } \\
\cdot 10^{-8}, \\
\mathrm{~kg} / \mathrm{s}\end{array}$ & 4.083 & 3.83 & 3.59 & 3.37 & 3.24 & 3.15 \\
\hline
\end{tabular}

The results (Table 7) show that, with increasing air humidity from 0 to $100 \%$, NO mass emission drops by a factor of 1.27 . This is the result of a decreasing maximum temperature and a local temperatures drop in the reaction zone.
To evaluate the impact of atmospheric air humidity on fuel combustion efficiency in the burner being investigated, the following relationship was considered:

$$
\Delta \mathrm{CH}_{4}=\left(\mathrm{G}_{\text {exh }} \mathrm{CH}_{4} \cdot 100\right) / \mathrm{G}_{\mathrm{int}} \mathrm{CH}_{4},
$$

where $\mathrm{ACH}_{4}$ is relative mass methane emission in the exhaust gases, $\mathrm{G}_{e x h} \mathrm{CH}_{4}$ is mass methane emission in exhaust gases $(\mathrm{g} / \mathrm{s}), \mathrm{G}_{\mathrm{int}} \mathrm{CH}_{4}$ is mass methane flow rate at the burner inlet $(\mathrm{g} / \mathrm{s})$.

Fig. 14 shows the variation of the relative mass methane emission in the exhaust gases vs. atmospheric air humidity.

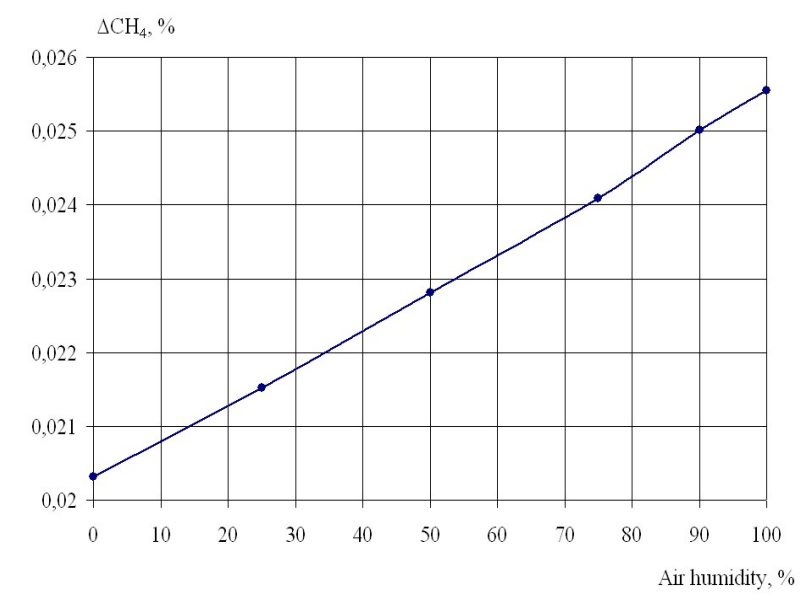

Figure 13. The variation of the relative mass methane emission in the exhaust gases vs. atmospheric air humidity.

The insignificant $\mathrm{ACH}_{4}$ increase is due to a maximum temperature drop and decreasing local temperatures in the reaction zone. Burner operation effectiveness can be increased by using secondary air and optimising the flow part.

\section{Conclusions}

The investigation results demonstrated the following: 
- the $k-\varepsilon$ turbulence model yields meaningful results during the simulation of the process of combustion of the methane-air mixture with high rates, in both the near-wall areas and in the burner central zone;

- atmospheric air humidity has a significant impact on the NO emission level;

- with increasing air humidity from 0 to $100 \%$, the NO mass emission drops by a factor of 1.27 due to a maximum temperature drop in the reaction zone (according to the Zeldovich thermal mechanism);

- air humidity in the range being investigated has virtually no effect on gas flow and flame velocity, and $\mathrm{CO}_{2}$ concentration in the exhaust gases;

- the study results can be used for appraising the parameters of gas burners and improving their environmental indicators.

\section{References}

[1] Patrylak L., Patrylak K., Okhrimenko M., Zubenko S., Levterov A.,Savytskyi V. Comparison of Power-Ecological Characteristics of Diesel Engine Work on Mixed Diesel Fuels on the Basis of Ethyl Esters of Rapeseed and Sunflower Oils. Chemistry \& Chemical Technology. 2015; 9:383-390.

https://doi.org/10.23939/chcht09.03.383

[2] Patrylak L., Patrylak K., Okhrimenko M., Ivanenko V., Zubenko S.,Levterov A., Marakhovskyi V., Savytskyi V. Ethanol containing ethyl esters of fatty acids as perspective environment like fuel. Fuel. 2013; 113:650653.

https://doi.org/10.1016/j.fuel.2013.06.020

[3] Albin E., Nawroth H., Göke S., D’Angelo Y., Paschereit C. Experimental investigation of burning velocities of ultra-wet methane-air-steam mixtures. Fuel
Processing Technology, Elsevier, 2013, vol. 107, pp. 2735.

https://doi.org/10.1016/j.fuproc.2012.06.027

[4] Goke S., Gockeler K., Kruger O., Paschereit C. Computational and experimental study of premixed combustion at ultra wet conditions. ASME Turbo Expo 2010, 2010, ASME Paper 2010-GT-23417. https://doi.org/10.1115/GT2010-23417

[5] Moëll D., Lörstad D., Bai X-S. Numerical Investigation of Methane/Hydrogen/Air Partially Premixed Flames in the SGT-800 Burner Fitted to a Combustion Rig. Flow, Turbulence and Combustion, 2016, vol. 96, no. 4, pp. 987-1003.

https://doi.org/10.1007/s10494-016-9726-5

[6] Büyükakın M., Öztuna S. Study on non premixed methane/air combustion from flame structure and NOX emission aspect for different burner head structures. Energy research, vol. 43, no. 10 2019, pp. 54215437.

https://doi.org/10.1002/er.4641

[7] Bidi M., Hosseini R., Nobari M.R.H.

Numerical analysis of methane-air combustion considering radiation effect. Energy Conversion and Management, 2008, vol. 49, no. 12 , pp. 3634-3647.

https://doi.org/10.1016/i.enconman.2008.07.010

[8] Aboje A. A., Umar Garba M., Abdulkareem A. S., Muzenda E., Faruq, A. A. Numerical modelling of pollutant formation in a lifted methane-air vertical diffusion flame. Cogent Environmental Science, 2017, vol. 3(1), 1302543.

https://doi.org/10.1080/23311843.2017.1302543

[9] Poinsot T, Veynante D. Theoretical and Numerical Combustion, R.T. Edwards Inc, 2005, pp. 522.

[10] Soroka B.S. Wet burning-the modern trend in environmental benign fuel combustion and in solution to the problem os sustainable development of the power generation. Alternative Energy and Ecology, 2018, vol. 2530, pp.96-117.

https://doi.org/10.15518/isjaee.2018.25-30.096-117

[11] Ferreira D. J. O., Sosa Arnao J. H., Moreira B. C., Rangel L. P., Park S. W. The impact of radiation 
in the gas combustion model for sugarcane bagasse grate boiler. Brazilian Journal of Chemical Engineering, 2016, vol. 33 , no. 3 .

\section{http://dx.doi.org/10.1590/0104-6632.20160333s20150143}

[12] Prieler R., Demuth M., Spoljaric D., Hochenauer C. Evaluation of a steady flamelet approach for use in oxy-fuel combustion. Fuel, 2014, vol. 118, pp. 55-68.

\section{https://doi.org/10.1016/i.fuel.2013.10.052}

[13] Trifonov O.V., Brega D.A.,Bolokhovets A.A., Palaziuk E.S. The combustion models and reaction mechanisms influence to the reliable prediction of the deflagration to detonation transition [Vliyaniye vybora modeley goreniya i mekhanizmov reaktsiy na dostovernost' prognozirovaniya perekhoda goreniya $\mathrm{v}$ detonatsiyu ]. Open information and computer integrated technologies, 2014, vol.63, pp.160-169.

[14] Levterov A.M., Levterova L.I., Gladkova $\mathrm{N}$.Yu. Formation of nitrogen monoxide and research of the influence on it emission of adjustable parameters of the engine and type used fuel [Obrazovaniye monooksida azota i issledovaniye vliyaniya na yego emissiyu reguliruyemykh parametrov dvigatelya $i$ vida ispol'zuemogo topliva]. Internal combustion engines, 2010, vol. 2, pp. 113-117.

[15] Tropina A. Nitrogen oxides formation during methane-air mixture [Obrazovaniye oksidov azota pri diffuzionnom gorenii metanovozdushnoy smesi]. Internal combustion engines, 2005, vol. 1, pp. 30-35.

[16] Zeldovich Y., Barenblatt G., Librovich V., Makhviladze G. The Mathematical Theory of Combustion and Explosion. Consultants Bureau, 1985, New York, NY, USA.

[17] Herbinet O., Pitz W., Westbrook C. Detailed chemical kinetic oxidation mechanism for a biodiesel surrogate. Combustion and Flame, 2008, vol. 154 (3), pp. 507-528.

\section{https://doi.org/10.1016/j.combustflame.2008.03.003}

[18] Huang W., Ma L., Pourkashanian M., Ingham D.B., Luo S-B., Liu J., Wang Z-G. Flow-Field
Analysis of a Typical Hydrogen-Fueled Dual-Mode Scramjet Combustor. Journal of Aerospace Engineering, 2012, vol. 25(3), pp. 336-346.

[19] Salim Salim M., Cheah, S.C. Wall y+ strategy for dealing with wall-bounded turbulent flows. Int. MultiConf. Eng. Comput. Sci. (IMECS), 2009, vol. 2, pp. $1-6$. 